\title{
YOUTH MOTIVES FOR PRACTICING SPORTS
}

\author{
Borka Malčić* \\ Faculty of Philosophy, University of Novi Sad, Serbia
}

\begin{abstract}
The aim of this study is to determine the motivational structure of youths for practicing sports. The research included 60 participants, of both sexes, all aged between 13 and 16. The survey method was applied. The research results showed the following facts: that intrinsic motivation is the main instigator for practicing sports and $58.33 \%$ of the participants personally made the decision to start doing sports. As for the structure of motives, health is in the first place of importance, followed by love for sports, then success, friendship, popularity and good looks. Money as primary motive is penultimate instigator, while fun is the last main motive for doing sports. The hierarchy of motives for initial involvement in sports activities does not differ on the basis of gender. Children are most intensively involved in sports between 6 and 10 years of age. The main conclusion of the research is that coaches should improve the consciousness of practicing sports for the purposes of fun and friendship.
\end{abstract}

Keywords: motivation, sports, physical activity, the youth.

\section{Introduction}

Movement is one of the very basic man's needs. We are today witnesses and victims of a lifestyle which includes long hours spent in front of the computer, TV monitor or behind a working desk, with an improper sitting posture, and excessive use of means of transportation (cars, buses, elevators), even for short-distance commuting. Children use buses on their way to school, even if it is only one bus stop away, or they have their parents take them by car. The mass phenomena of bad posture and flat feet have been detected in children attending junior elementary schools, along with many other consequences of hypokinesis. Taking into consideration all above mentioned facts, it is necessary that children and youth practice physical activity, that is, exercises, for the purpose of proper growth and development (psychophysical, social, as well as spiritual) and health in its most general sense. The greatest value of sports lies in nurturing sportsmanship spirit, which is characterized by ethics, fair play, team work, health, outstanding achievements, character and education, joy and fun, observance of rules and regulations, respect for oneself and other participants, courage, solidarity etc.

${ }^{*}$ Correspondingauthor. Faculty of Philosophy, University of Novi Sad, Dr Zorana Đinđića 2, 21000 Novi Sad, Serbia, e-mail: 
Research of the motivational aspects of the youth sport experience is a problem that has so far not been intensively dealt with by psychologists and educational experts. Bearing in mind that through sports a child develops communicational skills and improves interaction with other people, becomes better prepared to undertake responsibility and obligations, develops working habits, the sense of fair play and sportsmanship, learns about organizational skills and learns how to accept both victory and defeat, forms personal responsibility for taking risks and achieves many other useful purposes, it is needless to discuss the importance of doing sports and choosing a sports discipline that would suit the child best. Involving the youth in any organized sports activity, among its many other benefits, reduces the risk of sociopathologicalbehavior, such as delinquency and criminal conduct, alcohol consumption, drug abuse or prostitution. Age is not an obstacle for a child to start doing sports more intensively, even if he/she is very young, if training is led by highly qualified sports experts. In that sense, sport becomes a means for building up young people and develops certain traits of character which are basic for any other activity. The main aim of our research is to determine the motivational structure of the youth for doing sports and practicing sporting activities. Such formulation of the objective implies that basic reasons for which young people startpracticing sports should be determined, as well as the influences that made them opt for sport. Research results and data analysis are expected to lead to yet another anticipated objective of the research, namely, to improve the educational work in the field of sports and enable a higher-quality scientific design of sports activities. We expect our research to contribute to the clarification of the origins of sports activities for children. What is it that induces children to do sports and is there any difference between boys and girls in this matter?

Despite the fact that sport has a high potential for developing educational effect, only a few researchers have explored the issue of motivational aspects of the youth for practicing sports. During the 1970s and 1980s, research was carried out in the USA and it showed that most of the American children did sports for fun, because they liked doing something they were good at, in order to improve their sports skills, for the sake of challenge, competition, keeping in good shape, spending time with friends and making new friends (Gill, 1983; Gould and Petlichkoff, 1988). Until 1990, studies in motivation that were carried out in our country were mostly directed towards examining the degree to which achievement motives were expressed in adult sportspeople of various success rates, and towards the links between achievement motives and other personality dispositions (Havelka and Lazarević, 1981; Lazarević and Bačanac, 1985). In the early 1990s, Bačanac et al (Bačanac, Lazarević and Arunović, 1994) established the main reasons for which children and youth in Serbia usually opted for practicing sports, using the sample of 417 young sportspeople. They found that young people in our country start practicing sports primarily because they want to achieve success (advance towards a higher level), because of the attraction that a sports competition holds, because of their need to get in good shape, to do something they are good at, and to spend time with their friends. The latest research related to this issue was carried out in the USA in 1993. Its authors were Weiss and Ferrer-Caja. They reached firm conclusions on the three leading motives of children for doing sports. Firstly, children practice sports because they want to improve their physical fitness (athletic skills, physical abilities and physical appearance). The second motive for doing sports could be found in creating social acceptance and support (making friends, belonging to a group and obtaining support from parents and teachers). The third motive is related to fun and aims at increasing positive social experiences and reducing the negative ones.

The general hypothesis of the research was as follows: $\mathrm{Hg}-\mathrm{It}$ is assumed that today, in the time of economic crisis, as well as the crisis of general value system that society is faced with, motivational aspects of the young people for practicing sports are not of intrinsic (personal) quality. Based on the research tasks, specific hypotheses were derived from the general hypothesis. These are the following: H1 - It is assumed that health and love for sports represent individual motives that stand first in the hierarchy of the youths' motives for practicing sports and sports activities. $\mathrm{H} 2$ - It is assumed that, in Novi Sad, youth participation in sports activities 
is most intensive between the ages of six and ten. H3 - It is assumed that boys differ from girls as concerns their motivational structure for practicing sports. H4 - It is assumed that parents have influence on young people's decision to start doing sports and practicing sports activities.

\section{Method}

This research study included 60 participants, chosen among the students of senior elementary schools and first two grades of secondary schools, of both sexes, aged 13 to 16 and enrolled in sports clubs located at the territory of Novi Sad. Of the total number, 29 were female, and 31 were male. The research included the following sportspeople: 11 tennis players, 13 handball players, 15 water polo players and 21 volleyball players, all of them from national leagues.

The applied research techniques included survey and rating of importance of the stated reasons. The survey was carried out by a questionnaire for young people practicing sports. In order to examine the set research problem, we used a questionnaire that was designed independently for the purpose of this research study and with the aim to measure motivational characteristics of the youth for practicing sports. The introductory part of the questionnaire contains the instructions for filling out the questionnaire, information about the club at which the participant is a member and about the participant's gender. It contains 15 items, both open-ended and closed-ended, as well as a list of eight most frequent reasons for practicing sports, which was given to young participants so that they could rank the reasons according to the importance they had for their involvement in sports.

For data procession, the statistical package program "SPSS 8.0 for Windows" was used. Basic statistical parameters of descriptive statistics were calculated, and measures of average and correlation were made. On the basis of the recorded marginal frequency of participants' answers, we determined their distribution, which basically contained the middle values of each variable. This was carried out on the sample as a whole, as well as on the sub-samples determined according to gender. Chi-square test was applied for testing the differences in the distribution of answers between boys and girls, with level of significance of $\mathrm{p} \leq .05$.

\section{Results}

By analyzing the results, we reached the conclusion that $73.33 \%$ of the participants answered that their motives for doing sports are personal (Table 1). Young people of both sexes view sports primarily as a means of improving and preserving their own health. This motive was marked as primary by 24 participants $(40 \%)$. This motive is immediately followed by love for sports. 22 of the young participants put this motive in the first place on the scale of the offered motives, which represents $36.7 \%$. Success rated third in the hierarchy of the most important motives for doing sports (8.3\%). Friendship was listed as the primary motive by $6.6 \%$ of the participants. These are followed by popularity and looks with $3.3 \%$ of the participants who rated them first. Money serves as the basic motivation for youths' sports activities in $1.7 \%$ of cases. At the end no one among the young participants $(0 \%)$ sees fun as the basic motive for doing sports (Table 2). Youth involvement in sports is most intensive between the ages of six and ten (71.66\%), then between ten to fourteen (18.34\%), while at the very early ages, between four and six, the percentage is small $(10 \%)$. The mean value for the age at which the young participants started their involvement in sports and sports activities is 8.3 years (Table 3 ). The hierarchy of motives for initial involvement in sports activities does not defer on the basis of gender. The motivations to start playing sports are health and love for sports, with same percentage and it was 


\section{B. Malčić}

mostly present in the answers given by boys $(45.16 \%)$.Furthermore, success was mostly present in the answers given by girls (17.24\%), friendship by girls $(6.89 \%)$ and good looks and popularity by girls $(6.89 \%)$. At the end, fun as a primary motive for practicing sports is same for both sexes $(0 \%)$. Since $p=.374$ it could be said that by using method $\chi^{2}$ test no significant differences found between the youths' gender and their motives for involvement in sports(Table 4). Young people's predilection for their involvement in sports is primarily a personal decision (58.3\%) and other people's influences are proportionately smaller. Among other important people, under whose influence the young ones most frequently start practicing sports, we found parents in the first place $(15 \%)$, then friends $(11.7 \%)$, then other unnamed persons $(8.3 \%)$ and at the very end, sports idols (6.7\%) were listed as the reason that young people start doing a particular sport (Figure 1).

Table 1 shows resultsthe percentage prevalence of other influence for which young people start practicing sports.

Table 1

Numeric and percentage (\%) share of the nature of motives for which young people start practicing sports

I practicesportsonly because of my personal reasons

\begin{tabular}{llllll}
\hline Completelyagree & Mostlyagree & Cannotdecide & Tend to disagree & No answer & Total \\
\hline $44(73.33 \%)$ & $12(20 \%)$ & $2(3.33 \%)$ & $1(1.66 \%)$ & $1(1.66 \%)$ & $60(100 \%)$ \\
\hline
\end{tabular}

Table 2 shows numerical results of rankingmotivesby the degree ofimportancefrom first toeighth placeto startpracticing sportsfor both sexes. Offered motives were: Fun, Popularity, Money, Good looks, Love for sports, Health, Success and Friendship.

Table 2

Summary table of motives rated from 1 to 8 according to their importance as reasons for practicing sports

\begin{tabular}{ccccccccc}
\hline rank & Health & Success & Love for sports & Good looks & Friendship & Fun & Popularity & Money \\
\hline I place & 24 & 5 & 22 & 2 & 4 & 0 & 2 & 1 \\
II place & 14 & 10 & 15 & 3 & 5 & 4 & 1 & 5 \\
III place & 6 & 9 & 9 & 6 & 16 & 8 & 2 & 0 \\
IV place & 6 & 10 & 5 & 8 & 13 & 10 & 6 & 2 \\
V place & 1 & 8 & 2 & 8 & 11 & 18 & 6 & 5 \\
VI place & 2 & 12 & 3 & 10 & 5 & 5 & 16 & 8 \\
VII place & 2 & 5 & 1 & 12 & 2 & 5 & 20 & 12 \\
VIII place & 5 & 1 & 3 & 11 & 4 & 10 & 7 & 27 \\
\hline
\end{tabular}


Arithmetic means are presented in Table 3. Values of arithmetic meansindicatethat the youths in average start practicing sports when they are 8,3 years old.

Table 3

Average age at which youths start practicing sports

\begin{tabular}{cc}
\hline $\begin{array}{c}\text { Age at whichinvolvement in } \\
\text { sportsbegan }\end{array}$ & Number of participants \\
\hline 4years & 2 \\
5years & 4 \\
6years & 8 \\
7years & 11 \\
8years & 7 \\
9years & 7 \\
10years & 10 \\
11years & 8 \\
12years & 2 \\
13years & 0 \\
14years & 1 \\
Meanvalue & 8,3 years \\
\hline
\end{tabular}

Table 4 shows that there are no statistical significance $(\mathrm{p}=0.374)$ between boys and girls in motives they have to start practicing sports. Motives that were outlined by participants as the most important for practicing sports are given in numbers and percentages.

\section{Table 4}

Results of numeric (n), percentage (\%) and statistical significance gender-based share of the motives for which young people start practicing sports

\begin{tabular}{cccccccccc}
\hline & Health & Friendship & Success & Goodlooks & $\begin{array}{c}\text { Love for } \\
\text { Sports }\end{array}$ & Fun & Popularity & Money & Total \\
\hline Girls & 10 & 2 & 5 & 2 & 8 & 0 & 2 & 0 & 29 \\
& $(34.48 \%)$ & $(6.89 \%)$ & $(17.24 \%)$ & $(6.89 \%)$ & $(27.58 \%)$ & $(0.00 \%)$ & $(6.89 \%)$ & $(0.00 \%)$ & $(48.33 \%)$ \\
\hline Boys & 14 & 2 & 0 & 0 & 14 & 0 & 0 & 1 & 31 \\
& $(45.16 \%)$ & $(6.45 \%)$ & $(0.00 \%)$ & $(0.00 \%)$ & $(45.16 \%)$ & $(0.00 \%)$ & $(0.00 \%)$ & $(3.22 \%)$ & $(51.66 \%)$ \\
\hline Total & 24 & 4 & 5 & 2 & 22 & 0 & 2 & 1 & 60 \\
& $(40.00 \%)$ & $(6.66 \%)$ & $(8.33 \%)$ & $(3.33 \%)$ & $(36.66 \%)$ & $(0.00 \%)$ & $(3.33 \%)$ & $(1.66 \%)(100.00 \%)$ \\
\hline \multicolumn{7}{c}{} \\
\end{tabular}




\section{B. Malčić}

Figure 1

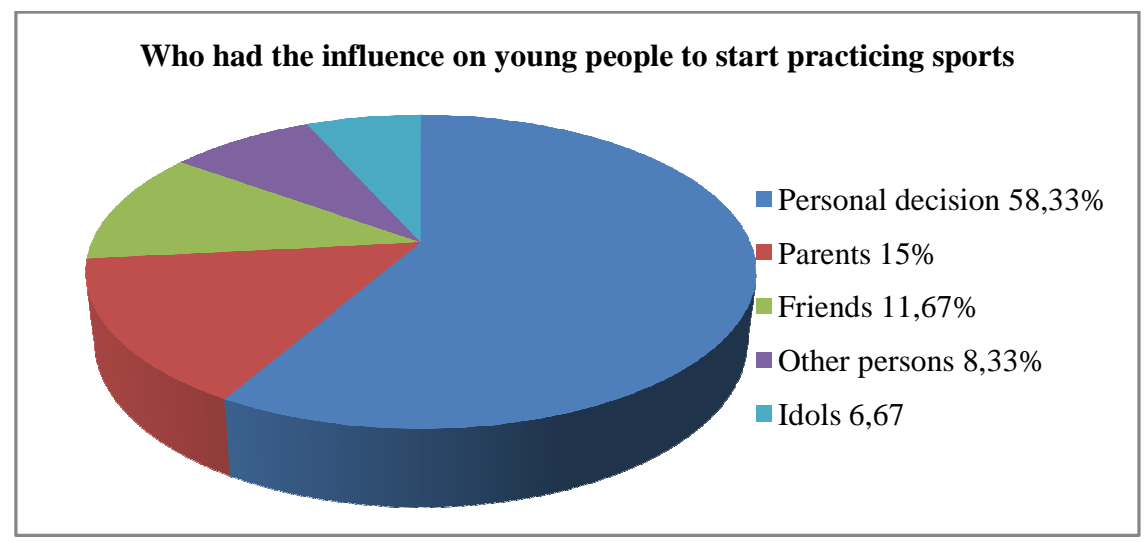

Figure 1 shows the percentage prevalence of other influence for which young people start practicing sports

\section{Discussion}

General hypothesis $\mathrm{Hg}$ - It is assumed that today, in the time of economic crisis, as well as the crisis of general value system that society is faced with, motivational aspects of the young people for practicing sports are not of intrinsic (personal) quality - was not confirmed. Young people decide for sports primarily for their personal motives. These results lead towards the conclusion that internal motivation is the dominant instigator for participation and continuous involvement in physical activities and sports. The H1 - It is assumed that health and love for sports represent individual motives that stand first in the hierarchy of the youths' motives for practicing sports - proved to be true. By analyzing results, we reached the conclusion that young people of both sexes view sports primarily as a means of improving and preserving their own health. We can conclude that all the data invariably confirm that young people view their sports activities as a factor in obtaining and preserving health, but also as an opportunity for achieving success and confirming their own competence, or as a place where they can spend time with their peers. Money, fun, popularity and good looks are not among the priority motives. Hypothesis $\mathrm{H} 2$ was confirmed - It is assumed that, in Novi Sad, youth participation in sports activities is most intensive between the ages of six and ten. The third hypothesis was H3 - It is assumed that boys differ from girls as concerns their motivational structure for doing sports. This hypothesis was not confirmed. There is no significant differencein the structureof motivesbetween boys and girls. The last hypothesis was $\mathrm{H} 4$ - It is assumed that parents have influence on young people's decision to start doing sports and practicing sports activities - and it proved incorrect. Young people's predilection for their involvement in sports is primarily a personal decision and other people's influences are proportionately smaller.

Limitations of this study might be found in its relatively small sample of participants, or in the territory where the research was conducted, considering that sports activities, and therefore also the motivational structure for the beginning of sports activities, generally depend on one's surroundings.

Although the only related research study that was carried out in the territory of Serbia (Bačanac, Lazarević and Arunović, 1994) shows that our young sportspeople start practicing sports for the prime purpose of achieving success, our research proves that, after some years, the youths' main motive has changed and that the awareness of healthy lifestyle reached through 
sports is now much more stressed in young population than it was fifteen years ago. What is more, when compared to the latest research carried out in America, the motivational structure here differs, primarily in the fact that in America, the primary motive is improvement in physical fitness, followed by improvement in social acceptance, belonging to a group and having friends, and lastly by the motive of having fun, which remarkably came in last in the hierarchy of motives in our study. The results of the mentioned research and complexity of the youths' motivational factors for practicing sports taken into consideration, we expect that this study will give proper contribution to the detection of these phenomena, and that the obtained results will find their application in the development of the pedagogy of sports.

Although it is believed that doing sports has positive influence on the physical, psychological and social development of young people, it should be noted that this influence does not appear automatically. In order for youths' involvement in sports to be used for the purpose of their optimal psychological and social development, the contents, organization, objectives and implementation of sports activities should be harmonized with the youths' interests, abilities, needs and expectations. A positive approach in sports and training implies that there is knowledge and satisfaction of motivational aspects that instigate young people to start doing sports, which is precisely the reason why this study is significant. This further implies that the basic task of the physical education expert and trainer should be to develop the youths' intrinsic motivation, as well as such motives, attitudes, value orientations and other personality dispositions that would form the basis for continuous practice of sports activities throughout their lifetime. The development of personal motivation is therefore an important pedagogical and psychological task of all those who work with young people. The condition for the fulfillment of this task is the application of all measures and actions which increase satisfaction, fun, pleasure and competence, and which are derived from all the contents of sports and physical education.

The core of every training session, discussion or other aspect of communication between the trainer and a sportsperson, is always a process of learning (Oljača, 2011), which points out the importance of the trainer and pedagogue figure in sports. In order to prompt the young people's wish to do sports, pedagogues and sports trainers should stress the contribution and role of each sportsperson and significance of both victory and defeat. They should point out the importance of observing rules and controlling one's behavior; they should nurture individualism and team work alike. Moreover, training sessions and sports activities in general should be diverse, in order to avoid boredom and satiation.

Sports and sports activities have so far made part of the educational process. Educators, trainers and sports experts should undertake the greatest part of responsibility for the youths' positive attitude towards sports, because the quality of young people's experiences with sports largely depends on their style of leading young sportspeople and on the relationship they have with them, and so do the youths' motives for doing sports and practicing sports activities. If the development of children in the spirit of sportsmanship is one of the goals of their upbringing, the research of the youths' motivational aspects for doing sports is then a task of crucial importance. As one of the few forms of activity that simultaneously engage body, intelligence and will, sports could in the future, and should, become the decisive factor in the development of young people and their better social integration.

\section{References}

Bačanac, Lj., Lazarević, Lj. \& Arunović, D. (1994). Karakteristike motivacije mladih Jugoslovenskih sportista za bavljenje sportom .Beograd: Sportska knjiga.

Čokorilo, R. (1998). Pedagogija sporta. Novi Sad: Viša škola za sportske trenere. 
Gill, D., Gross, J., \& Huddleston, S. (1983). Participation motivation in youth sports. International Journal of Sport Psychology 14, 1-14.

Gould, D., \& Petlichkoff, L. (1988). Participation Motivation and Attrition in Young Athletes. Champaign: Human Kinetics.

Havelka, N. \& Lazarević, Lj. (1981).Sport i ličnost. Beograd: Sportska knjiga.

Kozar, I. (2003). Korelati motoričko-morfološkog statusa, stavova i motivacije srednjoškolaca u fizičkom vaspitanju. [Correlates of secondary school students' motor and morphological status, attitudes and motivation for physical education].Novi Sad: Fakultet fizičke kulture.

Larson, R., Hansen, D., \& Dworkin, J.(2003). What adolescent learn from organized activities, Journal of Research on Adolescence, 13(1), 25-55.

Lazarević, Lj.,\&Bačanac, Lj. (1985). Achievement Motivation and Sports Activity. In 6th World Congress in Sport Psychology, Copenhagen, Denmark, 24-27 June.

McCullagh, P., Matzkanin, K.T., Shaw, S.D., \& Maldonado, M. (1993). Motivation for participation in physical activity: A comparison of parent-child perceived compentencies and participation motives. Pediatric Exercise Science, 5, 224-233.

Nešić, M. (2003). Motivacioni aspekti sporta. Bačka Palanka: LOGOS.

Oljača, M. (2001). Pedagogija sporta. Beograd: Sportska akademija.

Oljača, M. (2005). Pedagogija sportskog treninga. Beograd: Sportska akademija.

Ortanescu, D., \& Ortanescu C. (2001). Factors affecting the beginning and the continuing of athletic activity of 8-10 years old children. In: 10th World Congress of Sport Psychology: Programme and Proceedings (pp. 48-50). Skiathos: International Society of Sport Psychology (ISSP), Dēmokriteio Panepistēmio Thrakēs.

Radović, M., Bačanac, \& Lj., Vesković, A. (2005). Uloga porodice u sportskoj aktivnosti dece.Beograd: Fizička kultura, 59, 1-4.

Roberts, G.C., (1992). Motivation in Sport and Exercise. Champaign: Human Kinetics.

Theokas, C. (2009). Youth sports participation - View of issues: Introduction to the special selection, Development Psychologist, 45(2),303-306.

Weinberg, R. (1984). The Relationship Between Ertrinsic Rewards and Inrinsic Motivation in Sport. Champaing: Human Kinetics. 